\title{
PRAKTYCZNE ZASTOSOWANIE NOWOCZESNYCH TECHNOLOGII PODCZAS PROCESU REWITALIZACJI WIELKOPLYTOWEJ TKANKI MIEJSKIEJ, NA PRZYKLADZIE OSIEDLA PIASTOWSKIEGO W POZNANIU
}

\begin{abstract}
W przeciągu ostatnich lat projektanci nowopowstałych budynków mieszkaniowych walczą o upowszechnienie proekologicznych rozwiązań. Opisywany proces ma na celu poprawę warunków bytowych oraz stanu środowiska naturalnego. W ścisłej zabudowie miejskiej, a mianowicie w zabudowie wielkopłytowej, dostrzec można ogromny potencjał, który w ostatnich latach jest ignorowany. Wolne tereny między poszczególnymi jednostkami mieszkalnymi zostają uzupełniane o elementy nowoczesnej architektury. Proces ten ma negatywny wpływ na wizerunek tych struktur. Program rewitalizacji wielkopłytowej tkanki miejskiej należy poprzedzić szeregiem konsultacji społecznych uzupełnionych o możliwości zastosowania nowoczesnych technologii. Podobne inicjatywy są powszechnie realizowane za naszą zachodnią granicą. Realizacja proponowanych założeń powinna nastąpić w pełnej zgodzie z zasadami zrównoważonego rozwoju. Zmiana myślenia o modułowych przestrzeniach jest kluczowym krokiem w kierunku wdrożenia powyższych idei w opracowywanych projektach. Relikt przeszłości, jakim jest budynek z wielkiej płyty, może stać się czymś więcej niż tylko tymczasowym miejscem pobytu. Modułowa architektura XX wieku przejawia w swojej prostocie wiele interesujących rozwiązań, które $\mathrm{w}$ ówczesnych czasach były wręcz nowatorskie. Niestety na przestrzeni lat jej wizerunek uległ znaczącej degradacji. Wprowadzenie nowoczesnych technologii do obiektów może stać się szansą dla poszczególnych obszarów, bądź jednostek na rozwój. Zwiększenie funkcjonalności, naprawa wizerunku, a także rozwój aspektów ekologicznych uważa się powszechnie za niezbędne wytyczne, służące opracowaniu rzetelnego procesu rewitalizacyjnego. Proponowane założenia poprawią nie tylko sylwetkę przestrzenną, lecz przyczynią się również do rozwiązania wielu problemów socjologicznych.
\end{abstract}

Słowa kluczowe: wielorodzinne zespoły mieszkaniowe, rehabilitacja zabudowy modernistycznej, innowacyjność, funkcjonalność

\footnotetext{
1 Jarosław Zawadzki, Politechnika Poznańska, Wydział Budownictwa i Inżynierii Środowiska, ul. Piotrowo 5, 60-965 Poznań; tel. 796945110; studiobryly@gmail.com
} 


\section{Geneza modułowego budownictwa miejskiego}

Zmiany polityczno- ekonomiczne, jakie dostrzec można było w drugiej połowie XX wieku ukazują w sposób znaczny narastający deficyt mieszkaniowy, z jakim borykały się liczne organy administracji publicznej. Działania wojenne z lat 1939- 1945 wpłynęły na ogromną destrukcję potencjału struktury wielorodzinnej polskich miastach. W wielu przypadkach zniszczeniu uległo około $90 \%$ tkanki miejskiej. Wraz z nastaniem pokoju na terenie Europy wyraźnie odnotować można było zwiększenie migracji ludności do miast. W Polsce zjawisko to wynikało z chęci poprawy warunków życia. Powojenne miasta jednak nie spełniały podstawowych warunków społecznych, których potrzebowali mieszkańcy i migranci. Dlatego też koniecznym stało się opracowanie zarówno planów odbudowy przedwojennych struktur miejskich, jak również zaprojektowanie nowych przestrzenni mieszkaniowych, które $\mathrm{z}$ upływem czasu nabrały charakteru osiedli robotniczych. Wdrożony system budownictwa modułowego opracowany został w postaci zróżnicowanych form projektowych, lecz idea rozwiązania pozostała ta sama. Najważniejsze założenia przyświecające powyższemu programowi to: krótki czas wykonania poszczególnych jednostek mieszkalnych oraz duża liczba budynków na terenach podmiejskich. Głównymi elementami, które stanowiły przeszkodę dla rozwiązań architektoniczno- przestrzennych była ich schematyczność jak i powtarzalność [1]: „Jeżeli chodzi o kompozycje zespołów osiedli, to okres lat 1951-1953 a nawet 1954 przypada największe natężenie mody na zawartość i obrzeżność zabudowy, która spowodowała nieliczenie się z potrzebami przewietrzania wnętrz bloków, nadmierne zagęszczanie zabudowy pozbawiające mieszkańców terenów wypoczynku w pobliżu mieszkania, bagatelizowanie sprawy naświetlenia i nasłonecznienia zarówno mieszkań, jak i terenów śródblokowych itd. Przekroczenie wskaźników procentu zabudowy uważane było za osiągnięcie, a nie za błąd. Opisywany proceder rozpoczęty w latach pięćdziesiątych, trwał praktycznie do końca lat osiemdziesiątych". Pozostałość tych rozwiązań scharakteryzować można jako szeroko rozwinięte przestrzenie mieszkaniowe przeznaczone dla prawie 12 milionów mieszkańców, o zróżnicowanym położeniu zależnym od zapotrzebowania.

\section{Możliwości rewitalizacji wielkopłytowej tkanki miejskiej}

Obecnie coraz częściej pojawia się na forum publicznym opinia, że rzetelny proces rewitalizacji wielkopłytowej tkanki miejskiej jest czymś koniecznym. Liczne audyty i ekspertyzy konstrukcyjne jedynie to potwierdzają. Przeprowadzone przez grono naukowców badania przeprowadzone na terenie Osiedla Piastowskiego w Poznaniu podkreślają wyraźnie fakt, że zastana struktura wytrzyma jeszcze około 150 lat [2]. Uwzględniając przedstawione idee, szerokie grono architektów i urbanistów skłania się do podjęcia wyzwania opracowania nowoczesnego programu rewitalizacyjnego. Program ten miałby się opierać na ścisłej 
współpracy projektantów oraz organów administracyjnych z mieszkańcami. Działania mające na celu ochronę modułowej tkanki osiedlowej wdrażane były podczas współpracy mieszkańców z organami administracyjnymi w trakcie sporządzania miejscowego planu zagospodarowania przestrzennego ${ }^{2}$. Akt prawa miejscowego w sposób nieprzekraczalny definiuje przestrzeń wewnątrzosiedlową. Założenia dokumentu chronią stan zastany pod względem architektonicznourbanistycznym. Idea programu przedstawia także liczne założenia związane $\mathrm{z}$ rozwojem osiedla $\mathrm{w}$ postaci obiektów rekreacji indywidualnej oraz małej architektury w postaci ławek, koszy na śmieci, itp. Jednakże w dokumencie nie ma mowy o działaniach naprawczych nakreślonych dla poszczególnych jednostek mieszkalnych. Jedyny fragment poruszający kwestie modernizacji dotyczy wyłącznie elementów zewnętrznych sieci, które związane są z obsługą techniczną budynku. Nieuwzględnienie szczegółowych możliwości modernizacyjnych przekreśla $\mathrm{w}$ dużej mierze szanse poprawy wizerunku miejskiego zastanej przestrzeni. Przeprowadzone autorskie badanie w sposób klarowny ukazuje zaangażowanie mieszkańców w proces rewitalizacji.

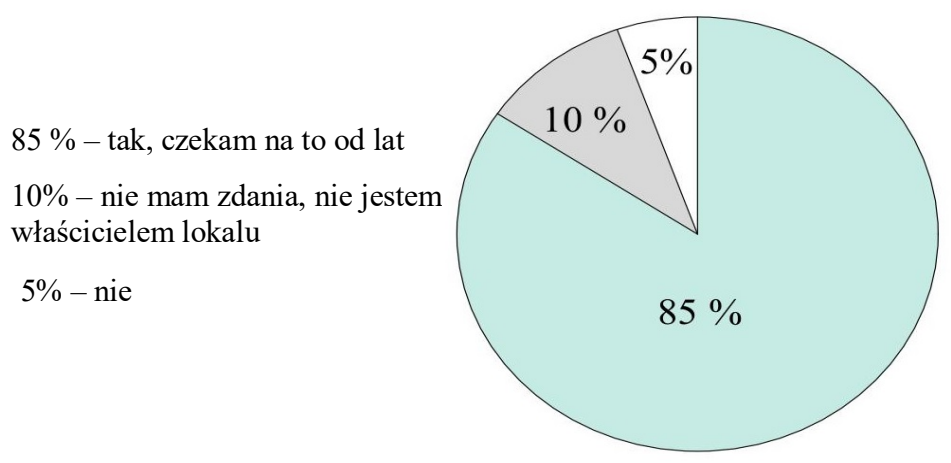

Rys. 1. Wykres ilustrujący aprobatę mieszkańców Os. Piastowskiego wobec wdrożenia planu rewitalizacji

Fig. 1. Diagram showing the approval of Os. Piastowskiego residents for the implementation of the revitalization plan

W ostatnim czasie zauważyć można liczne zabiegi związane z ponownym wykorzystaniem zdegradowanego potencjału mieszkaniowego. Opracowanie tego typu koncepcji przyczyniłoby się do rozwiązania licznych problemów socjologicznych, a także w sposób znaczny poprawiłoby wizerunek miejski. Rozwiązania powszechnie stosowane przez naszych zachodnich sąsiadów mogą stać się dla nas pewną bazą doświadczeń. Proces rehabilitacji zabudowy mieszkaniowej z drugiej połowy XX wieku uwzględniałby podstawowe czynniki, które

\footnotetext{
${ }^{2}$ Treść uchwały opracowanej dla Osiedla Piastowskiego, pochodząca ze strony Miejskiej Pracowni Urbanistycznej w Poznaniu
} 
są obecnie najczęściej poruszane przez lokatorów i zarząd administracyjny. Do głównych postulatów należą $\mathrm{m}$. in.:

- zwiększenie funkcjonalności wewnętrznego układu lokalowego,

- korekta zewnętrznej estetyki jednostek mieszkalnych,

- wprowadzenie elementów nowoczesnych technologii,

- zwiększenie atrakcyjności terenów zielonych.

Wzrost znaczenia funkcjonalności wewnętrznych układów mieszkaniowych [3] należy rozumieć jako wprowadzenie programu dwupoziomowych lokali. Do 1967 roku budynki tworzono z wykorzystaniem technologii konstrukcji zamkniętej. Potem jednak większość obiektów typu OWT-67 oraz W-70 posiada otwartą konstrukcję umożliwiającą ingerencję w wewnętrzny układ. Proponowany dwupoziomowy układ zaobserwować można w istniejących już budynkach pochodzących z XX wieku. Takie rozwiązanie występuje między innymi w Jednostce Marsylskiej ${ }^{3}$, zaprojektowanej przez Le Corbusiera jako tzw. maszyna do mieszkania. Idea dwukondygnacyjnych lokali opracowana została w tym przypadku wg. pierwotnego projektu, lecz uzyskanie podobnych efektów $\mathrm{w}$ polskich realiach pozwoliłoby osiągnąc zamierzony poziom innowacyjności. Opisując stagnację powyższych układów wielorodzinnych nie sposób nie wspomnieć o ich estetyce zewnętrznej, a także nagminnie postępującym procesie ,pastelozy”. Wprowadzenie oryginalnej, nieco bardziej stonowanej estetyki elewacji przyczyniłoby się do poprawy wizerunku modułowych osiedli. Powiązanie elewacji z możliwościami, które daje nowoczesna technologia, może być ku temu doskonałą okazją. Przeznaczenie górnej płaszczyzny obiektu pod realizację zielonych dachów pozwoli nadać miejscu swoistą markę, tzw. „,brandscape" [4]. Wykreowanie nowej marki miejsca pozwoliłoby w sposób definitywny odseparować się od pastelowego układu, a dzięki powszechności wielkiej płyty istnieje szansa na stworzenie serii oryginalnych założeń.

\section{Modernizacja $\mathrm{z}$ uwzględnieniem nowoczesnych technologii}

Podczas procesu rewitalizacji należałoby rozpatrzeć zastosowanie nowoczesnych technologii w kwestii zewnętrza oraz wnętrza zastanej struktury. Mianowicie mowa tutaj o wdrożeniu ujednoliconego planu, który działałby na dwóch płaszczyznach. Jeżeli chodzi o układ zewnętrzny istotnym elementem jest doświetlenie przestrzeni wspólnych, czyli ciągów komunikacyjnych, placów, itp. Obecnie zastosowane oprawy oświetleniowe w postaci lamp sodowych są bardzo wydajne, lecz charakteryzują się przede wszystkim dużym poborem mocy. Mimo wszystko, wymiana wspomnianych opraw na oświetlenie typu

\footnotetext{
${ }^{3}$ Unité d'Habitation, czyli Jednostka Marsylska: modernistyczny budynek o charakterze zabudowy wielorodzinnej zaprojektowanej przez Le Corbusiera. Samowystarczalny budynek, dzięki idei architekta posiadający dostęp do sieci usługowej oraz rekreacyjnej, które zlokalizowane są wewnątrz
} 
LED pozwoliłoby na oszczędzenie środków, które z powodzeniem można byłoby przeznaczyć na inne cele, np. modernizację zielonych struktur wewnątrzosiedlowych. Przewidywane oszczędności obrazuje rys. 2. Opisywane przedsięwzięcie jest powszechnie stosowane $\mathrm{w}$ wielu aglomeracjach miejskich. Zabieg jest kosztowny, lecz wyniki stopy zwrotu zainwestowanych funduszy są niezwykle zadowalające.

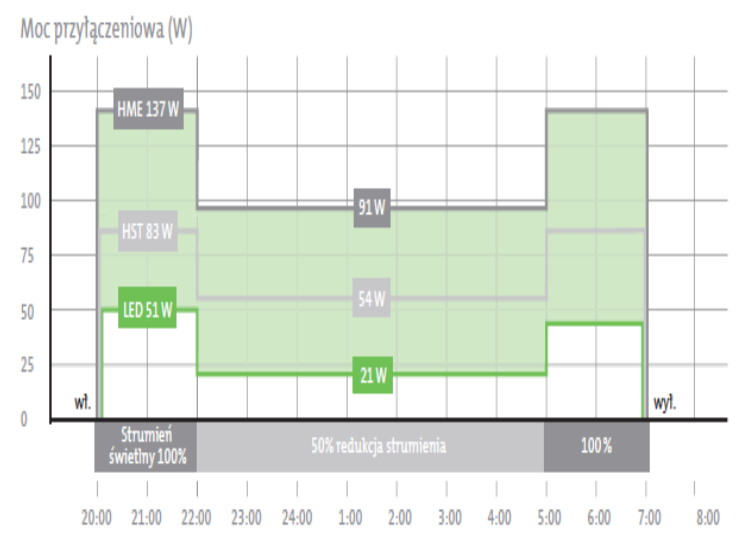

Rys. 2. Zestawienie zużycia pobieranej mocy przez standardowe oprawy oświetleniowe, a także oprawy typu LED, na podstawie [5]

Fig. 2. Comparison of power consumption from standard lighting fixtures and LED lights, based on [5]

Kolejnym ważnym krokiem ku modernizacji jest należyte wykorzystanie zewnętrznych elewacji poszczególnych jednostek mieszkalnych [6]. Jedną z możliwości jest wprowadzenie do obiektów aparatury służącej do pozyskiwania energii ze źródeł odnawialnych. Podobne zabiegi dostrzec można w wielu krajach zachodnich. Ze względu na powszechne, jednolite zastosowanie, cieszą się one dużą aprobatą ze strony użytkowników. Mowa tutaj o wykorzystaniu elewacji do montażu ogniw fotowoltaicznych lub kolektorów słonecznych. W przypadku wspomnianego już Osiedla Piastowskiego w Poznaniu, jednostki mieszkalne o wysokości 16 kondygnacji, posiadają ściany boczne od strony południowego zachodu, a więc w sposób bardzo korzystny jeśli chodzi o pobór energii słonecznej. Zastosowane tego typu rozwiązania pozwoliłoby na pozyskanie nadwyżki energii, która mogłaby posłużyć do oświetlenia np. wewnętrznych przestrzeni wspólnych. Zastosowane kolektorów słonecznych umożliwiłoby zaopatrzenie w bieżąca ciepłą wodę całego budynku, dzięki czemu zabieg przyczyniłby się nie tylko do zaoszczędzenia pieniędzy, ale pomógłby również zredukować emisję $\mathrm{CO}_{2}$. 


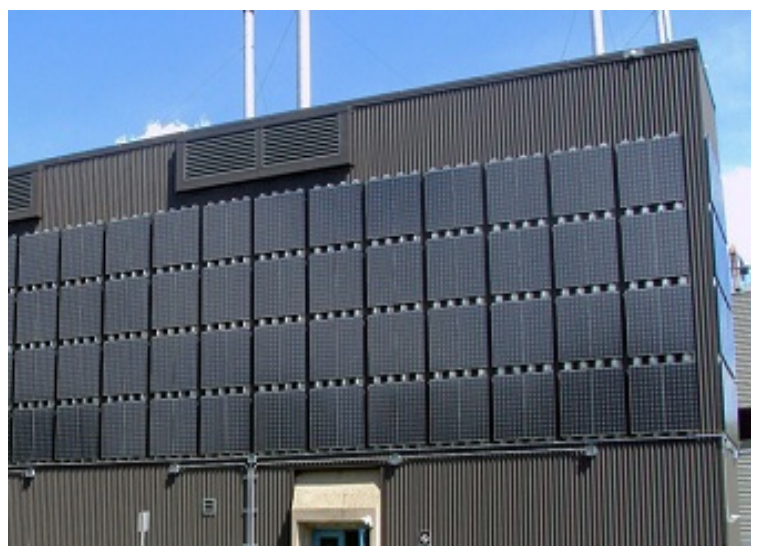

Rys. 3. Przykład zastosowywania ogniw na zewnętrznych elewacjach budynków, na podstawie [7]

Fig. 3. Example of photovoltaic cells on the outer facades of buildings, based on [7]

Poruszając zagadnienie energetyki cieplnej należy wspomnieć o założeniach mających na celu zwiększenie oszczędności oraz maksymalizację potencjału budynku. Mowa tutaj o pozyskiwaniu energii cieplnej z urządzeń związanych z obsługą serwerów oraz przekazywaniu wspomnianej nadwyżki cieplnej do ogrzewania poszczególnych przestrzeni budynku. Takie rozwiązanie zostało już wdrożone w wielu polskich realizacjach, m. in. w Starym Browarze i PCSS w Poznaniu. Zwiększenie wykorzystania dolnych przestrzeni obiektów wielkopłytowych pozwoliłoby zlokalizować w poszczególnych dolnych partiach sieć serwerów obsługująca nie tylko wskazane jednostki mieszkalne, lecz i wybrane fragmenty miasta. Obecnie wielu dostawców mediów boryka się z problemem braku lokalizacji aparatury, dlatego też realizacja tego projektu pozwoliłaby uzyskać obopólne korzyści dla mieszkańców i dostawców. Poruszając kwestie energetyczne wymienić należy także inne systemy pozyskiwania energii. Adekwatnym przykładem jest system windowy OTIS Gen2 Switch Regen, dzięki któremu możliwe jest odzyskanie sporej ilości energii podczas ruchu opadającej kabiny windowej. Rozwiązanie zastosowane będzie w tzw. Miejskim Budynku Jutra, realizowanego na warszawskim Żoliborzu. Obiekt budowlany został zaprojektowany jako demonstracyjny według zasad budownictwa ekologicznego [9]. 


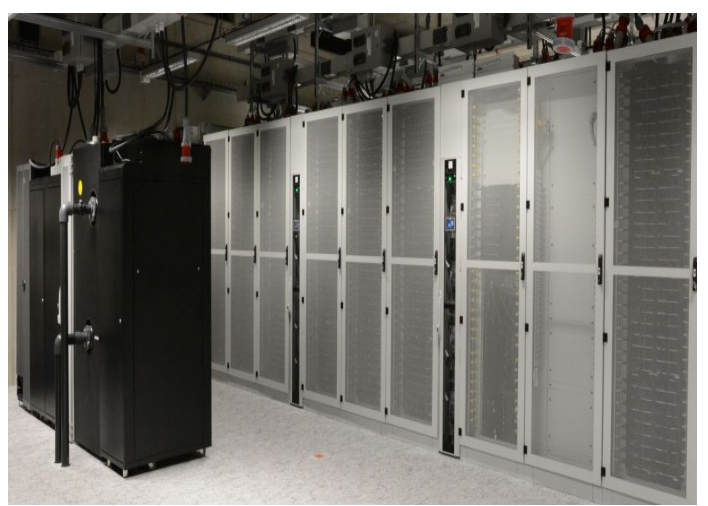

Rys. 4. Superkomputer „Orzeł”, zlokalizowany w PCSS w Poznaniu, z którego uzyskiwana nadwyżka ciepła przekazywana jest do ogrzewania budynku, na podstawie [8]

Fig. 4. The "Orzeł" ("Eagle") supercomputer, located in PSNC in Poznań; the excess heat from it is used to heat the building, based on [8]

\section{Wnioski}

Opisując powyższe koncepcje dostrzec można wiele możliwości, które niosą nowoczesne technologie. Ich zastosowanie jest jednak w wielu przypadkach kosztowne. Postęp technologiczny wiąże się z niebywałymi możliwościami, które w sposób znaczny mogą ułatwić życie mieszkańcom, jak również wpłynąć na zmniejszenie kosztów eksploatacyjnych. Rozwój zdegradowanych struktur budownictwa modułowego za pomoca innowacji technologicznych pozwoli zmodernizować budownictwo rynku wtórnego, dzięki czemu wielka płyta może ponownie stać się obiektem marzeń oraz konkurować z nowopowstałymi obiektami.

\section{Literatura}

[1] Nadolny A., Sobczyńska- Jeżewska K., Projekty poznańskich osiedli z lat 1945-1989 a ich obecny kształt, Wydawnictwo Politechniki Poznańskiej, Poznań 2011, s. 12-19.

[2] Rozwadowska A., Wielka płyta postoi jeszcze 150 lat, Głos Wielkopolski, Poznań 2013.

[3] Gronostajska B., Kreacja i modernizacja przestrzeni mieszkaniowej, Wydawnictwo Politechniki Wrocławskiej, Wrocław 2007, s. 183-194.

[4] Bonenberg W., Architektura jako marka miasta- na przykładzie aglomeracji poznańskiej, Czasopismo Techniczne, Kraków 2012.

[5] http://docplayer.pl/9115403-Oswietlenie-przestrzeni-miejskiej.html \{dostęp 03.05.2016 r.\}.

[6] Chmielewski J., Mirecka M., Modernizacja osiedli mieszkaniowych, Oficyna Wydawnicza Politechniki Warszawskiej, Warszawa 2007, s. 197-269.

[7] http://www.rynekinstalacyjny.pl/aktualnosc/id6443,kolektory-powietrzne \{dostęp 10.04.2016 r.\}. 
[8] http://www.telix.pl/artykul.php?sid=71922 \{dostęp 15.03.2016 r.\}.

[9] http://www.muratorplus.pl/inwestycje/inwestycje-mieszkaniowe/krasinskiego-41fort-development-buduje-na-warszawskim-zoliborzu-miejski-budynek-jutra-2030 _80075.html \{dostęp 08.06.2016 r.\}.

\section{PRACTICAL APPLICATION OF MODERN TECHNOLOGIES IN THE PROCESS OF URBAN REVITALIZATION OF LARGE-PANEL URBAN FABRIC, BASED ON THE EXAMPLE OF OSIEDLE PIASTOWSKIE IN POZNAN}

\section{S u m m a r y}

In recent years, designers of new residential buildings have been fighting for the expansion of eco-friendly solutions. The process described is intended to improve living standards and the state of the environment. There is great potential in the dense urban fabric, especially in the largepanel buildings, that has been completely ignored in recent years. The free spaces between residential units are currently filled out with elements of modern architecture. This process has a detrimental influence on the look of the structures. The large-panel urban fabric revitalization program should be preceded by a number of social consultations along with the possible implementation of modern technologies. Similar initiatives are widespread in countries to the West of Poland. The implementation of the proposed changes should occur in a steady manner to ensure sustainable development. Changing our way of thinking about modular spaces is a crucial step towards the implementation of the ideas presented in the projects. Thanks to them, the large-plate building, seemingly a relic of the past, can become something more than simply a temporary place of residence. The modular architecture of the $20^{\text {th }}$ century offers many interesting solutions through its simplicity - solutions that were quite innovative for their time. Sadly, over the years its looks has deteriorated significantly. Implementing modern technologies to the buildings may become a chance for development for specific areas and units. Increasing functionality, repairing the building's image, and a greater emphasis on eco-friendliness are widely considered to be crucial guidelines, integral to providing a thorough and comprehensive revitalization process. The proposed tenets will not only help improve the spatial appearance, but also solve many sociological problems.

Keywords: multifamily housing complexes, rehabilitation of modernist buildings, innovation, functionality

Przestano do redakcji: $23.05 .2016 r$.

Przyjęto do druku: 15.09.2017 r. 